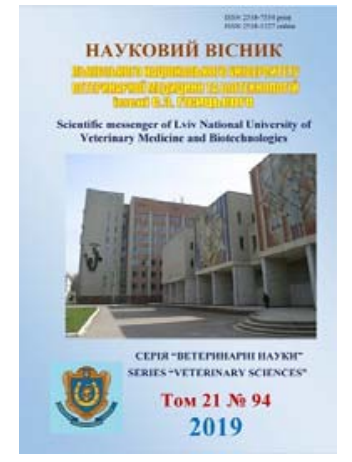

Науковий вісник Яьвівського національного університету
ветеринарної медицини та біотехнологій імені С.3. Гжицького. Серія: Ветеринарні науки

Scientific Messenger of Lviv National University of Veterinary Medicine and Biotechnologies. Series: Veterinary sciences

ISSN 2518-7554 print ISSN 2518-1327 online doi: $10.32718 /$ nvlvet 9420

http://nvlvet.com.ua

\title{
Morphological and biochemical parameters of blood of rats for the long-term effect of the drug "Vitosept"
}

\author{
M.P. Soltys \\ Stepan Gzhytskyi( Grzycki) National University of Veterinary Medicine and Biotechnologies, Lviv, Ukraine
}

Article info

Received 15.04.2019

Received in revised form 15.05.2019

Accepted 16.05.2019

Stepan Gzhytskyi National University of Veterinary Medicine and Biotechnologies Lviv, Pekarska Str., 50, Lviv, 79010, Ukraine. Tel.:+38-067-323-51-40 E-mail: soltysmaria88@gmail.com
Soltys, M.P. (2019). Morphological and biochemical parameters of blood of rats for the long-term effect of the drug "Vitosept". Scientific Messenger of Lviv National University of Veterinary Medicine and Biotechnologies. Series: Veterinary sciences, 21(94), 109-114. doi: 10.32718/nvlvet9420

The basis of the drug "Vitosept" is a solution of high-purity sodium hypochlorite (SH), which is obtained in a specially developed dyadiafragm flow electrolyzer, in the process of direct electrochemical reaction, bypassing the formation of molecular chlorine. As an initial electrolyte, an isotonic solution of sodium chloride $(0.9 \% \mathrm{NaCl})$ was prepared on water purified by a special technology. Such solutions do not contain impurities of organic substances and transition metal ions. The resulting solution of SH is the optimal carrier of active oxygen. The purpose of the study was to find out the effects of various dosage of the drug "Vitosept" for its intravenous introduction, in a long-term experiment. As a result of the conducted experiments, it was found that during the entire observation period of the investigated drug "Vitosept" signs of inadequate reaction, intoxication or death of animals were not observed. At the same time, there were no reservations regarding behavioral reactions, reflex excitability, clinical manifestations of respiratory distress, urinary excision and defecation. Only animals of the 4th group, after administration of the highest dosage of the drug $(500 \mathrm{mg} / \mathrm{l})$, were slightly suppressed, were slightly responsive to acoustic and light stimuli, had somewhat disturbed reflex excitability. However, an hour after the cessation of giving the drug, the evidence of all the animals in this group disappeared. It was found out that for long-term intradermal introduction to the laboratory animals of the drug "Vitosept" at dosages of 50 and $100 \mathrm{mg} / \mathrm{l}$, the abnormalities in the studied morphological and biochemical parameters of blood, compared to the same in the control group were not found. Concerning the rats of the IV group that received the highest study dosage of the drug $(500 \mathrm{mg} / \mathrm{l})$ through the probe, certain possible changes in the hematological, biochemical parameters of blood (leukocyte count increase in blood, activity of AsAT, LF, decrease in serum urea blood concentration, creatinine) were observed, in our opinion, compensatory and disappeared within a few days after discontinuation of the drug. Consequently, taking into account our previous studies on the establishment of the parameters of acute toxicity of the drug "Vitosept" and the results obtained regarding its effects on hemopoiesis and the functional state of the liver and kidneys, it can be argued that the drug "Vitocet" belongs to the IV class of compounds - low toxicity.

Key words: chronic toxicity, sodium hypochlorite antioxidant and proteinsynthesis function of the liver.

\section{Морфологічні та біохімічні показники крові щурів за довготривалої дії препарату "Вітосепт"}

\author{
М.П. Солтис
}

Львівський національний університет ветеринарної медицини та біотехнологій імені С.3. Гжицького, м. Львів, Україна

В основі препарату “Вітосепт” є розчин високочистого натрію гіпохлориту (ВНГХ), який одержаний в спеціально розробленому бездіафрагмовому проточному електролізері в прочесі прямої електрохімічної реакиії, минаючи процес утворення молекулярного хлору. Як вихідний електроліт використовували ізотонічний розчин натрію хлориду (0,9\% NaCl), приготовлений на воді, очищеній за спеціальною технологією. Такі розчини не містять домішок органічних речовин та іонів перехідних металів. Отриманий розчин ВНГХ є оптимальним носієм активного кисню. Завданням дослідження було з'ясувати вплив різних доз препарату 
“Вітосепт” за внутрішлункового його введення в умовах довготривалого досліду. В результаті проведених експериментів встановлено, щуо впродовж всього періоду спостереження досліджуваного препарату “Вітосепт” ознак неадекватної реакиї, інтоксикації чи загибелі тварин не спостерігали. При иььму застережень щзодо поведінкових реакцій, рефлекторної збудливості, клінічних проявів порушення дихання, акту сечевиділення та дефекачії не відзначено. Лите тварини IV групи, після введення вітосепту в найвищій досліджуваній дозі (500 мг/л) були дещзо пригнічені, слабо реагували на звукові та світлові подразники, мали дещзо порушену рефлекторну збудливість. Однак вже через годину після припинення дачі препарату дані ознаки у всіх тварин иієї групи зникали. 3'ясовано, щзо за довготривалого внутрішлункового введення лабораторним тваринам препарату “Вітосепт” у дозах 50 i 100 мг/л відхилень у досліджуваних морфологічних і біохімічних показниках крові порівняно з аналогічними у контрольної групи не виявлено. Стосовно шурів IV групи, які отримували через зонд найвищу досліджувану дозу препарату (500 мг/л), виявлені окремі вірогідні зміни гематологічних, біохімічних показників крові (зростання в крові числа лейкочитів, активності АсАТ, ЛФ, зменшення концентрації в сироватці крові сечовини, креатиніну) носили, на нашу думку, компенсаторний характер $і$ зникали впродовж кількох днів після припинення введення препарату. Отже, з урахуванням наших попередніх досліджень зі встановлення параметрів гострої токсичності препарату “Вітосепт” та отриманих результатів щуодо його впливу на гемопоез та функиіональний стан печінки і нирок можна стверджувати, щуо препарат “Вітосепт” належить до IV класу сполук - малотоксичні.

Ключові слова: хронічна токсичність, гіпохлорит натрію, антитоксична і протеїнсинтезувальна функція печінки.

\section{Вступ}

В основі препарату “Вітосепт” є розчин високочистого натрію гіпохлориту (ВНГХ), який одержаний в спеціально розробленому бездіафрагмовому проточному електролізері, в процесі прямої електрохімічної реакції, минаючи процес утворення молекулярного хлору. Як вихідний електроліт використовували ізотонічний розчин натрію хлориду $(0,9 \% \mathrm{NaCl})$, приготовлений на воді, очищеній за спеціальною технологією. Такі розчини не містять домішок органічних речовин та іонів перехідних металів. Отриманий розчин ВНГХ є оптимальним носієм активного кисню (Kotsiumbas \& Velychenko, 2009).

Нашими попередніми дослідженнями встановлено, що препарат "Вітосепт” не токсичний, швидко виводиться 3 організму, легко віддає активний кисень та може проникати через білкові бар'єри (Ganzhar \& Novikov, 1979; Malinin et al., 2002; Kotsiumbas et al., 2006).

Метою наших досліджень було з'ясування можливої шкідливої дії досліджуваного препарату “Вітосепт" за довготривалого надходження в організм лабораторних тварин, виявлення найбільш чутливих до нього органів і систем та встановлення можливості зворотного відновлення функцій на тлі застосування препарату. Завданням дослідження було з'ясувати вплив різних доз препарату "Вітосепт" за внутрішньошлункового його введення в умовах довготривалого досліду.

\section{Матеріал і методи досліджень}

Досліди на лабораторних тваринах проводились у віварії ДНДКІ ветпрепаратів та кормових добавок (м. Львів). Експериментальні дослідження виконувались згідно з методами і методиками, які описані в монографії “Доклінічні дослідження ветеринарних лікарських засобів” (2006). Токсикологічну оцінку препарату "Вітосепт" проводили згідно з методичними рекомендаціями “Токсикологічний контроль нових засобів захисту тварин” (1997).

Експерименти на тваринах проводили відповідно до правил Європейської конвенції про захист хребетних тварин, що використовуються в експериментах i для інших наукових цілей (ETS №123. Страсбург, 1986) та ухвали Першого національного конгресу 3 біоетики (Київ, 2001).

Дослідження проводили на 80 білих безпородних щурах, віком 4-5 місяців, масою тіла 180-190 г, які утримувалися на стандартному раціоні (з вільним доступом до води). Дослід тривав 30 діб. За принципом аналогів було сформовано чотири групи тварин, по 20 у кожній. Препарат "Вітосепт” по 5 мл вводили щоденно, внутрішньошлунково, за допомогою зонду 3 тупим кінцем. Тварини I-ої групи (контрольної) отримували по 5 мл фізрозчину; дослідні групи щурів отримували 5 мл препарату "Вітосепт" з різною концентрацією ВНГХ: II група - 50 мг/л; III група $100 \mathrm{мг/л} \mathrm{і} \mathrm{IV} \mathrm{-} 500$ мг/л.

Клінічні спостереження впродовж досліду проводили, реєструючи терміни можливого розвитку токсикозу та загибель тварин. На 10-ту і 20-ту доби по 5 щурів із кожної групи зважували і декапітували за умов легкого ефірного наркозу та відбирали кров для подальших досліджень.

Отриману гепаринізовану кров від щурів центрифугували при 3000 об. протягом 15 хв. Плазму відділяли, а еритроцити 2 рази промивали охолодженим фізіологічним розчином 3 наступним центрифугуванням при 3000 об. протягом 15 хв. Еритроцити використовували для визначення еритроцитарного індексу інтоксикації.

Дослідження гематологічних і біохімічних показників крові проводили за методами, описаними в довіднику “Фізіолого-біохімічні методи досліджень у біології, тваринницві та ветеринарній медицині” (Vlizlo, 2012).

\section{Результати та їх обговорення}

Кров завдяки своїй реактивності, постійному руху та виконанню ряду функцій відіграє ключову роль у розвитку адаптації за дії на організм різних токсичних чинників (Martyshuk et al., 2016; Gutyj et al., 2017; Todoriuk et al., 2018). Нами вивчено вплив препарату "Вітосепт" на важливі параметри гомеостазу організму досліджуваних щурів - гематологічні показники. Отримані результати представлені в таблиці 1. 
Таблиця 1

Гематологічні показники у щурів на 10-ту добу досліду за умов довготривалого введення препарату “Вітосепт”, $(\mathrm{M} \pm \mathrm{m}, \mathrm{n}=5)$

\begin{tabular}{lrrrr}
\hline \multicolumn{1}{c}{ Показники } & \multicolumn{3}{c}{ Групи тварин / Концентрація “Вітосепту”, мг/л } \\
\cline { 2 - 5 } & I. Контроль & \multicolumn{1}{c}{ II. -50} & \multicolumn{1}{c}{ III. -100} & IV. -500 \\
\hline Гематокрит, \% & $39,1 \pm 0,63$ & $40,7 \pm 0,71$ & $39,1 \pm 0,43$ & $38,9 \pm 1,96$ \\
Гемоглобін, Г/л & $123,9 \pm 1,95$ & $125,0 \pm 1,74$ & $125,0 \pm 1,05$ & $114,5 \pm 5,67$ \\
Еритроцити, Т/л & $7,16 \pm 0,13$ & $7,33 \pm 0,12$ & $6,97 \pm 0,10$ & $6,58 \pm 0,32$ \\
Сер. вміст Нb в еритр., пг & $16,9 \pm 0,14$ & $17,4 \pm 0,21$ & $17,4 \pm 0,30$ & $17,7 \pm 0,13$ \\
Сер. вміст Нb в еритр., \% & $31,5 \pm 0,08$ & $31,5 \pm 0,15$ & $31,8 \pm 0,15$ & $30,2 \pm 0,39$ \\
Сер. Об'єм еритр., мкм ${ }^{3}$ & $53,8 \pm 0,48$ & $55,3 \pm 0,61$ & $55,2 \pm 0,62$ & $58,0 \pm 0,46$ \\
Пок. анізоцитозу ерит, \% & $14,9 \pm 0,14$ & $14,5 \pm 0,16$ & $14,4 \pm 0,15$ & $13,9 \pm 0,13$ \\
\hline
\end{tabular}

Відзначаємо, що за аналізом табл. 1 виявлено незначні коливання досліджуваних показників у щурів, які не виходили за межі контролю і фізіологічної норми для даного виду тварини. Стан периферичної крові у щурів, які отримували препарат “Вітосепт" теж був в межах фізіологічних величин і не зазнавав критичних змін.

\section{Таблиця 2}

Лейкограма щурів на 10-ту добу досліду за умов вивчення субхронічної токсичності препарату “Вітосепт", $(\mathrm{M} \pm \mathrm{m}, \mathrm{n}=5)$

\begin{tabular}{lcccc}
\hline \multicolumn{1}{c}{ Показники } & \multicolumn{3}{c}{ Групи тварин / Концентрація “Вітосепту, мг/л } \\
\cline { 2 - 5 } & I. Контроль & II. -50 & III. -100 & IV. -500 \\
\hline Лейкоцити, Г/л & $5,2 \pm 0,44$ & $5,7 \pm 0,43$ & $6,8 \pm 0,29$ & $7,43 \pm 0,53$ \\
Нейтрофіли, \% & $33,2 \pm 7,9$ & $32,9 \pm 6,6$ & $34,8 \pm 5,3$ & $38,0 \pm 3,1$ \\
Паличкоядерні, \% & $1,20 \pm 0,44$ & $1,10 \pm 0,43$ & $0,80 \pm 0,29$ & $1,43 \pm 0,53$ \\
Сегментоядерні, \% & $22,0 \pm 2,46$ & $21,8 \pm 2,87$ & $19,0 \pm 1,92$ & $30,8 \pm 4,41$ \\
Еозинофіли, \% & $0,60 \pm 0,27$ & $1,20 \pm 0,25$ & $1,10 \pm 0,23$ & $0,57 \pm 0,30$ \\
Моноцити, \% & $0,80 \pm 0,39$ & $0,90 \pm 0,31$ & $0,80 \pm 0,20$ & $2,43 \pm 0,53$ \\
Лімфоцити,\% & $65,4 \pm 2,68$ & $65,0 \pm 2,96$ & $63,0 \pm 2,06$ & $59,0 \pm 4,03$ \\
\hline
\end{tabular}

В лейкограмі характерним було збільшення відносної кількості моноцитів і, навпаки, зниження відсотка лімфоцитів (табл. 2).

Динаміка біохімічних показників сироватки крові у щурів за вивчення субхронічної токсичності досліджуваного препарату подана в таблиці 3. За аналізом отриманих результатів можна зробити висновок, що за довготривалого внутрішлункового введення вітосепту в дозі 50 мг/л вірогідних змін досліджуваних біохімічних показників крові дослідної групи щурів на 10-ту добу добу досліду не відзначено. Щодо лабо- раторних тварин третьої групи (доза препарату 100 мг/л) - у них вірогідно зменшувався вміст загального протеїну в сироватці крові на $5,2 \%(\mathrm{P}<0,05)$ i більш ніж у 1,5 разу активність лужної фосфатази порівняно 3 контролем. За найвищої досліджуваної дози препарату "Вітосепт" у крові щурів IV групи крім зміни рівня протеїну і активності лужної фосфатази, які продовжували зменшуватись, вірогідно низьким був також вміст білірубіну прямого та активність $\gamma$-амілази $(\mathrm{P}<0,05)$.

\section{Таблиця 3}

Біохімічні показники сироватки крові щурів на 10-ту добу досліду за умов вивчення субхронічної токсичності препарату “Вітосепт”, (M $\pm \mathrm{m}, \mathrm{n}=5)$

\begin{tabular}{|c|c|c|c|c|}
\hline \multirow{2}{*}{ Показники } & \multicolumn{4}{|c|}{ Групи тварин / Концентрація “Вітосепту”, мг/л } \\
\hline & I. Контроль & II. -50 & III. -100 & IV. -500 \\
\hline Білірубін заг., мкмоль/л & $11,4 \pm 0,3$ & $11,1 \pm 0,64$ & $11,7 \pm 0,37$ & $11,4 \pm 1,05$ \\
\hline Білірубін прям., мкмоль/л & $3,05 \pm 0,2$ & $2,41 \pm 0,21$ & $2,08 \pm 0,46$ & $0,89 \pm 0,18 *$ \\
\hline АсАТ, Е/л & $160,7 \pm 9,1$ & $190,3 \pm 11,2$ & $205,2 \pm 18,3$ & $168,4 \pm 5,32$ \\
\hline АлАТ, Е/л & $47,1 \pm 2,1$ & $53,2 \pm 2,43$ & $53,4 \pm 2,14$ & $52,8 \pm 1,32$ \\
\hline Коефіцієнт Рітіса & $3,53 \pm 0,2$ & $3,69 \pm 0,23$ & $3,93 \pm 0,48$ & $3,20 \pm 0,18$ \\
\hline Сечовина, ммоль/л & $8,23 \pm 0,3$ & $7,41 \pm 0,24$ & $7,39 \pm 0,32$ & $7,81 \pm 0,45$ \\
\hline Креатинін, ммоль/л & $45,1 \pm 0,8$ & $42,6 \pm 1,08$ & $40,8 \pm 1,85$ & $41,1 \pm 1,74$ \\
\hline Лужна фосфатаза, Е/л & $404,7 \pm 36,8$ & $324,9 \pm 36,2$ & $248,4 \pm 22,1 *$ & $151,5 \pm 8,93 *$ \\
\hline Альфа-амілаза загал., E/л & $502,0 \pm 22,4$ & $453,3 \pm 20,1$ & $457,7 \pm 18,6$ & $392,7 \pm 23,9 *$ \\
\hline Глюкоза, ммоль/л & $5,99 \pm 0,18$ & $6,32 \pm 0,12$ & $6,22 \pm 0,10$ & $5,60 \pm 0,27$ \\
\hline
\end{tabular}


Функціональний стан нирок характеризують рівень сечовини і креатиніну в сироватці крові піддослідних щурів. Нами з'ясовано, що при введенні препарату "Вітосепт" у трьох тестових концентраціях у щурів усіх дослідних груп тенденційно знижувався вміст сечовини і креатиніну в крові, хоч дані показни- ки і не виходили за межі фізіологічних величин, характерних для даної групи тварин.

При дослідженні протеїнового профілю сироватки крові встановлено, що на тлі хоч і незначного але вірогідного зниження рівня загального протеїну у щурів IV дослідної групи, фракційний його склад змінювався неоднозначно (табл. 4).

\section{Таблиця 4}

Фракційний склад протеїнів сироватки крові щурів на 10-ту добу досліду за умов вивчення субхронічної токсичності препарату “Вітосепт”, $(\mathrm{M} \pm \mathrm{m}, \mathrm{n}=4)$

\begin{tabular}{lcccc}
\hline \multicolumn{1}{c}{ Показники } & \multicolumn{3}{c}{ Групи тварин / Концентрація “Вітосепту”, мг/л } \\
\cline { 2 - 5 } & I. Контроль & II. -50 & III. -100 & IV. -500 \\
\hline Заг.протеїн, г/л & $67,0 \pm 1,13$ & $64,9 \pm 0,86$ & $64,6 \pm 0,95$ & $62,9 \pm 0,84^{*}$ \\
Альбумін, \% & $49,9 \pm 4,43$ & $49,5 \pm 4,41$ & $49,0 \pm 2,83$ & $48,7 \pm 4,72$ \\
$\alpha_{1}$-глобуліни, \% & $10,6 \pm 0,84$ & $10,2 \pm 0,64$ & $9,0 \pm 1,37$ & $11,7 \pm 0,42$ \\
$\alpha_{2}$-глобуліни, \% & $10,5 \pm 0,20$ & $11,4 \pm 0,93$ & $9,80 \pm 1,3$ & $9,70 \pm 0,28$ \\
$\beta$-глобуліни, \% & $15,45 \pm 0,37$ & $13,5 \pm 0,78$ & $13,6 \pm 0,29$ & $18,5 \pm 0,44^{*}$ \\
$\gamma$-глобуліни, \% & $13,55 \pm 0,26$ & $15,40 \pm 0,04$ & $18,6 \pm 0,43^{*}$ & $11,4 \pm 0,88$ \\
\hline
\end{tabular}

Примітка: вірогідність до показників контролю: * $\mathrm{P}<0,05$

Так, вміст альбумінів дещо знижувався, порівняно 3 тваринами контрольної групи. Щодо глобулінів, то характерним було тенденційне зростання вмісту $\alpha_{1}$ глобулінів за зниження рівня $\alpha_{2}$-глобулінів. $\beta$ глобуліни за найвищої дослідної дози вітосепту (500 мг/л) зростали в сироватці крові щурів IV групи на $19,7 \%(\mathrm{P}<0,05)$, а в крові щурів III групи рівень $\gamma$ глобулінів був на $38,6 \%(\mathrm{P}<0,05)$ вищим, ніж у тварин контролю.
За оцінкою морфологічних показників крові лабораторних щурів на 20-у добу досліду (табл. 5) встановлено, що вірогідних відхилень від контролю не було, хоча на тлі незначного збільшення в крові тварин IV дослідної групи еритроцитів вміст гемоглобіну був нижчим на 5,8\%. Динаміка показників, які характеризують середній об'єм та насиченість еритроцитів гемоглобіном у щурів контрольної і дослідних груп була не характерною.

\section{Таблиця 5}

Гематологічні показники у щурів на 20-ту добу досліду за вивчення субхронічної токсичності препарату "Вітосепт", $(\mathrm{M} \pm \mathrm{m}, \mathrm{n}=5)$

\begin{tabular}{lrrr}
\hline \multicolumn{1}{c}{ Показники } & \multicolumn{3}{c}{ Групи тварин / Концентрація “Вітосепту”, мг/л } \\
\cline { 2 - 4 } & \multicolumn{1}{c}{ І. Контроль } & II. -50 & III. -100 \\
\hline Гематокрит, \% & $39,6 \pm 1,36$ & $41,3 \pm 1,17$ & $40,1 \pm 1,33$ \\
Гемоглобін, г/л & $123,7 \pm 1,55$ & $125,4 \pm 1,68$ & $125,1 \pm 1,35$ \\
Еритроцити, Т/л & $7,16 \pm 0,13$ & $7,23 \pm 0,16$ & $7,57 \pm 0,18$ \\
Сер. вміст Нь в еритр., пг & $16,9 \pm 0,44$ & $16,4 \pm 0,32$ & $18,4 \pm 0,45$ \\
Сер. вміст Нь в еритр., \% & $31,5 \pm 0,08$ & $30,7 \pm 0,16$ & $29,6 \pm 0,18$ \\
Сер. об'єм еритр., мкм ${ }^{3}$ & $54,8 \pm 0,48$ & $56,3 \pm 0,41$ & $57,3 \pm \pm 0,27$ \\
Пок. анізоцитозу ерит, \% & $14,3 \pm 0,14$ & $14,5 \pm 0,16$ & $14,6 \pm 0,15$ \\
\hline
\end{tabular}

При аналізі лейкограми крові дослідних щурів на 20-ту добу досліду за умов вивчення субхронічної токсичності препарату "Вітосепт" виявлено, що зміни клітин крові не були суттєвими. Стан периферичної крові у щурів в цей період досліду був в межах фізіологічної норми і не зазнавав жодних критичних змін (табл. 6).

Результати біохімічних досліджень сироватки крові тварин на 20-ту добу досліду за впливу препарату "Вітосепт" наведені в таблиці 7. На тлі зростання активності аспартатамінотрансферази $(\mathrm{P}<0,05)$ у тварин, яким задавали вітосепт у дозі 500 мг/л (IV група), коефіцієнт Де-Рітіса тенденційно знижувався (табл. 7). На зниження функціонального стану печінки і нирок у щурів вказувало також зниження в сироватці їх крові концентрації білірубіну прямого на $46,2 \%$ (Р < 0,05), сечовини - 5,1\% і креатиніну - на 8,9\% відповідно. Характерною також була динаміка щодо зниження активності окремих ензимів, зокрема лужної фосфатази (на 41,6\%) $(\mathrm{P}<0,05)$ і $\alpha$-амілази на 20,6\% (P < 0,05). Стосовно досліджуваних біохімічних показників крові лабораторних тварин II і III дослідних груп (50 і 100 мг/л препарату) вірогідних відхилень від цифрових даних щурів групи контролю не виявлено. 


\section{Таблиця 6}

Лейкограма щурів на 20-ту добу досліду за умов вивчення субхронічної токсичності препарату “Вітосепт", $(\mathrm{M} \pm \mathrm{m}, \mathrm{n}=5)$

\begin{tabular}{lccc}
\hline \multicolumn{1}{c}{ Показники } & \multicolumn{3}{c}{ Групи тварин / Концентрація “Вітосепту”, мг/л } \\
\cline { 2 - 4 } & I. Контроль & II. -50 & III. - 100 \\
\hline Лейкоцити, Г/л & $8,2 \pm 0,44$ & $7,1 \pm 0,43$ & $10,8 \pm 0,29$ \\
Нейтрофіли, \% & $34,7 \pm 5,1$ & $35,4 \pm 4,6$ & $36,1 \pm 5,3$ \\
Паличкоядерні, \% & $1,20 \pm 0,44$ & $1,4 \pm 0,10 \pm 0,43$ & $0,80 \pm 0,29$ \\
Сегментоядерні, \% & $20,5 \pm 2,46$ & $21,8 \pm 2,87$ & $19,0 \pm 1,92$ \\
Еозинофіли, \% & $0,60 \pm 0,27$ & $1,20 \pm 0,25$ & $1,10 \pm 0,23$ \\
Моноцити, \% & $0,80 \pm 0,39$ & $0,90 \pm 0,31$ & $0,80 \pm 0,20$ \\
Лімфоцити, \% & $63,9 \pm 2,68$ & $62,5 \pm 2,46$ & $62,0 \pm 2,06$ \\
\hline
\end{tabular}

\section{Таблиця 7}

Біохімічні показники сироватки крові щурів на 20-ту добу досліду за умови вивчення субхронічної токсичності препарату “Вітосепт”, (M $\pm \mathrm{m}, \mathrm{n}=5)$

\begin{tabular}{lcccc}
\hline \multicolumn{1}{c}{ Показники } & \multicolumn{3}{c}{ Групи тварин / Концентрація “Вітосепту”, мг/л } \\
\cline { 2 - 5 } & І. Контроль & II. -50 & III. -100 & IV. -500 \\
\hline Білірубін заг., мкмоль/л & $11,4 \pm 0,3$ & $11,1 \pm 0,64$ & $11,9 \pm 0,37$ & $12,4 \pm 1,05$ \\
Білірубін прям., мкмоль/л & $3,01 \pm 0,25$ & $2,41 \pm 0,21$ & $2,08 \pm 0,46$ & $1,39 \pm 0,18^{*}$ \\
АсАТ, Е/л & $161,7 \pm 9,1$ & $166,3 \pm 5,2$ & $176,2 \pm 8,3$ & $201,4 \pm 5,62^{*}$ \\
АлАТ, Е/л & $47,1 \pm 2,1$ & $53,2 \pm 2,43$ & $53,4 \pm 2,14$ & $52,8 \pm 1,32$ \\
Коефіціснт Де-Рітіса & $3,53 \pm 0,2$ & $3,69 \pm 0,23$ & $3,93 \pm 0,48$ & $3,20 \pm 0,18$ \\
Сечовина, ммоль/л & $8,23 \pm 0,3$ & $7,41 \pm 0,24$ & $7,39 \pm 0,32$ & $7,81 \pm 0,45$ \\
Креатинін, ммоль/л & $45,1 \pm 0,8$ & $42,6 \pm 1,08$ & $40,8 \pm 1,85$ & $41,1 \pm 1,74$ \\
Лужна фосфатаза, Е/л & $402,5 \pm 26,4$ & $354,9 \pm 23,2$ & $288,6 \pm 21,1 *$ & $167,5 \pm 5,62^{*}$ \\
Альфа-амілаза загал., Е/л & $502,0 \pm 22,4$ & $483,6 \pm 18,9$ & $453,7 \pm 19,9$ & $398,7 \pm 23,5 *$ \\
Глюкоза, ммоль/л & $5,99 \pm 0,18$ & $6,22 \pm 0,12$ & $6,21 \pm 0,10$ & $5,81 \pm 0,27$ \\
\hline
\end{tabular}

Примітка: вірогідність до показників контролю: * $\mathrm{P}<0,05$

Нами з'ясовано, що за довготривалого введення щурам вітосепту в досліджуваних дозах $(100$ i 500 мг/л) у тварин знижувалась протеїнсинтезувальна функція (табл. 8). Так, на 20-ту добу досліду в сирова- тці крові тварин цих груп (III, IV) рівень загального протеїну був нижчим на 7,6 (P < 0,05) і $11,3 \%$ (P < 0,05) відповідно.

\section{Таблиця 8}

Фракційний склад протеїнів сироватки крові щурів на 20 добу досліду за умов вивчення субхронічної токсичності препарату “Вітосепт”, $(\mathrm{M} \pm \mathrm{m}, \mathrm{n}=4)$

\begin{tabular}{lrrrc}
\hline \multicolumn{1}{c}{ Показники } & \multicolumn{3}{c}{ Групи тварин / Концентрація “Вітосепту”, мг/л } \\
\cline { 2 - 5 } & I. Контроль & II. -50 & III. -100 & IV. -500 \\
\hline Загальний протеїн, г/л & $63,5 \pm 1,31$ & $62,97 \pm 1,74$ & $58,7 \pm 1,64 *$ & $56,3 \pm 1,76^{*}$ \\
Альбуміни, \% & $50,8 \pm 1,23$ & $49,5 \pm 2,31$ & $48,0 \pm 1,83$ & $48,8 \pm 3,27$ \\
$\alpha_{1}$-глобуліни, \% & $12,7 \pm 0,53$ & $10,2 \pm 0,34$ & $12,6 \pm 0,67$ & $9,8 \pm 0,42$ \\
$\alpha_{2}$-глобуліни, \% & $10,5 \pm 0,22$ & $11,4 \pm 0,97$ & $10,8 \pm 0,93$ & $9,6 \pm 0,48$ \\
$\beta$-глобуліни, \% & $13,3 \pm 0,27$ & $14,3 \pm 0,48$ & $15,4 \pm 0,29$ & $16,9 \pm 0,54^{*}$ \\
$\gamma$-глобуліни, \% & $12,7 \pm 0,24$ & $14,6 \pm 0,24$ & $13,2 \pm 0,43$ & $14,9 \pm 0,98$ \\
\hline
\end{tabular}

Примітка: вірогідність до показників контролю: * $\mathrm{P}<0,05$

При цьому відзначено, що зниження концентрації протеїну в крові відбувається за рахунок зменшення відсотка альбумінів та вірогідного підвищення протеїнів $\beta$-глобулінової фракції.

\section{Висновки}

За довготривалого внутрішлункового введення лабораторним тваринам препарату "Вітосепт" у дозах 50 і 100 мг/л відхилень у досліджуваних морфологічних і біохімічних показниках крові, порівняно $з$ аналогічними у контрольної групи не виявлено. Стосовно щурів IV групи, які отримували через зонд найвищу досліджувану дозу препарату (500 мг/л), виявлені окремі вірогідні зміни (зростання в крові числа лейкоцитів, активності АсАТ, ЛФ, зменшення концентрації в сироватці крові сечовини, креатиніну) носили, на нашу думку, компенсаторний характер і зникали впродовж кількох днів після припинення введеня препарату. Отже, з урахуванням наших попередніх досліджень $з$ встановлення параметрів гострої токсичності препарату "Вітосепт" та отриманих результатів щодо до його впливу гемопоез та функціональний стан печінки і нирок можна стверджувати, що препа- 
рат “Вітосепт” належить до IV класу сполук - малотоксичні.

Перспектива подальшого дослідження полягає у 3'ясуванні ембріотоксичних та тератогенних властивостей препарату “Вітосепт” на організм білих щурів.

\section{References}

Ganzhar, P.S., \& Novikov, A.A. (1979). Uchebnoe posobie po klinicheskoj toksikologii. M.: Kolos (in Russian).

Gutyj, B., Khariv, I., Binkevych, V., Binkevych, O., Levkivska, N., Levkivskyj, D., \& Vavrysevich, Y. (2017). Research on acute and chronic toxity of the experimental drug Amprolinsyl. Regul. Mech. Biosyst., 8(1), 41-45. doi: 10.15421/021708.

Gutyj, B., Martyshchuk, T., Bushueva, I., Semeniv, B., Parchenko, V., Kaplaushenko, A., Magrelo, N., Hirkovyy, A., Musiy, L., \& Murska, S. (2017). Morphological and biochemical indicators of blood of rats poisoned by carbon tetrachloride and subject to action of liposomal preparation. Regulatory Mechanisms in Biosystems, 8(2), 304-309. doi: 10.15421/021748.

Kotsiumbas, I.Ia., \& Velychenko, O.B. (2009). Perspektyvy zastosuvannia hipokhlorytiv $\mathrm{u}$ veterynarnii medytsyni. L.: TzOV "VF Afisha" (in Ukrainian).

Kotsiumbas, I.Ia., Malyk, O.H., Petereha, I.P. ta in. (2006). Doklinichni doslidzhennia veterynar-nykh likarskykh zasobiv. Lviv: Triada plius (in Ukrainian).

Malinin, O.A., Hmel'nickij, G.A., \& Kucan, A.T. (2002). Veterinarnaja toksikologija.

Korsun'Shevchenkovskij: ChP Majdachenko (in Russian).

Martyshuk, T.V., Gutyj, B.V., \& Vishchur, O.I. (2016). Level of lipid peroxidation products in the blood of rats under the influence of oxidative stress and under the action of liposomal preparation of "Butaselmevit", Biological Bulletin of Bogdan Chmelnitskiy Melitopol State Pedagogical University, 6(2), 22-27. doi: 10.15421/201631.

Todoriuk, V.B., Hunchak, V.M., Gutyj, B.V., Gufriy, D.F., Hariv, I.I., Khomyk, R.I., \& Vasiv, R.O. (2018). Preclinical research of the experimental preparation "Ferosel T". Ukrainian Journal of Veterinary and Agricultural Sciences, 1(1), 3-9. doi: 10.32718/ujvas1-1.01.

Vlizlo, V.V. (2012). Laboratorni metody doslidzhen u biolohii, tvarynnytstvi ta veterynarnii medytsyni. Dovidnyk za redaktsiieiu. Lviv: Spolom (in Ukrainian). 